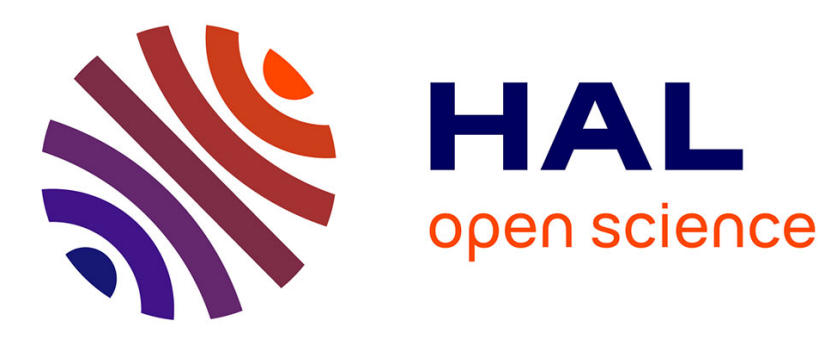

\title{
Global Contests in the Production of Business Knowledge :
}

Vincent Mangematin, Charles Baden-Fuller

\section{To cite this version:}

Vincent Mangematin, Charles Baden-Fuller. Global Contests in the Production of Business Knowledge :: Regional Centres and Individual Business Schools. Long Range Planning, 2007, 47 (1), pp.2007. 10.1016/j.lrp.2007.11.005 . hal-00422658

\section{HAL Id: hal-00422658 \\ http://hal.grenoble-em.com/hal-00422658}

Submitted on 8 Oct 2009

HAL is a multi-disciplinary open access archive for the deposit and dissemination of scientific research documents, whether they are published or not. The documents may come from teaching and research institutions in France or abroad, or from public or private research centers.
L'archive ouverte pluridisciplinaire HAL, est destinée au dépôt et à la diffusion de documents scientifiques de niveau recherche, publiés ou non, émanant des établissements d'enseignement et de recherche français ou étrangers, des laboratoires publics ou privés. 
For Publication in Long Range Planning: Volume 41 (1) 2007

\title{
Global Contests in the Production of Business \\ Knowledge:
}

\section{Regional Centres and Individual Business Schools}

\author{
Vincent Mangematin \\ Grenoble Ecole Management and UMR GAEL (INRA/UPMF), France \\ vincent@grenoble.inra.fr \\ Charles Baden-Fuller* \\ Cass Business School, London, EC1Y 8TZ, UK \\ c.baden-fuller@city.ac.uk
}

* Corresponding author

\begin{abstract}
Drawing on institutional theory, the global production of business research is analysed by examining the system of written outputs using one of the largest databases of journal papers ever assembled, covering over 65,000 articles produced by more than 54,000 authors from over 8,000 different institutions across the period 1992-2005. We begin by pointing out how the US business schools pioneered the modern institutional system of undertaking and disseminating research that involves the intertwining of and university business schools and journals. While Wharton and Harvard are still the leading universities globally, their crowns are slipping, together with the position of the US generally. We observe the greatest challenges to the existing order as coming from European and Asian institutions that have either copied, or been inspired to innovate by adapting, the US system. London Business School, Erasmus, INSEAD and Tilburg are threatening to topple leading US universities in the undertaking of research, and other European and Asian institutions are close behind. It is argued that international businesses can now go to non-US institutions to find leaders in thought.

\section{Acknowledgements}

We thank Kerstin Salhin, Rodolphe Durand and Marie Laure Djelic for useful comments and the Journal's Editors, Robert Grant, Hugh Courtney and Simon Peck, for their comprehensive reviews and encouragement to publish this piece. This piece was subject to open rather than blind review.
\end{abstract}

All data sets and their analysis (C) V. Mangematin \& C. Baden-Fuller, 2007, to be reproduced by Elsevier Science under licence.

Onward copying only permitted with written permission 


\section{Global Contests in the Production of Business Knowledge}

\section{Introduction}

Business Schools play a critical role in the production, collation and dissemination of business knowledge through degree programmes, executive education, basic research, and consultancy. In common with all academic institutions, basic research forms a key element of the workload of the typical faculty member in any top business school. ${ }^{1}$ The doctoral training that a faculty member receives prior to working is focused on the skills required to produce original knowledge, and newly recruited faculty members in top schools will be required to devote perhaps $30 \%$ or more of their time to basic research that lead to some kind of academic publication. ${ }^{2}$ This basic research covers the broad spectrum of business activities, some of which will form the basis of new thinking for the classroom and for tools used by corporations (see for instance the evidence from AACSB or Harmon for a critical analysis ${ }^{3}$ ).

The business school research agenda has been steadily globalising, and the US model has been influential in setting up the norms. Until the mid 1980s, basic management research was deeply embedded in national cultures: US journals initially only published the work of US academics, while outside the US most journals were nationally-focussed, written in the local language, stylised for local consumption, and poorly disseminated internationally. ${ }^{4}$ While some of this non-US research was truly influential, ${ }^{5}$ in many cases the distinction between scholarship and research was vague, in the way the research was both undertaken and written up. Many pieces were no more than replication and translation of ideas initiated in US Business Schools and contained little that was new.

Since the mid 1980s things have changed. First there have been changes in the context: interactions amongst economies have been rising and international management practices are emerging. Multinational corporations and large domestic firms in non-English speaking countries have adopted English as their second (or even first) business language, and have used US based or trained consultants to introduce US Management Practices. ${ }^{6}$ These ideas have been reinforced by the popularity of MBA and executive training courses that utilise US styled teaching cases, text-books, practice oriented books, and international journals with a professional orientation such as Harvard Business Review, California Management Review, Sloan Management Review and Long Range Planning. 
In parallel with these changes in business, US universities started $\mathrm{PhD}$ programmes in management that recruited students globally and trained them to high standards. In parallel, US journals began to accept contributions from non-US academics and to be much more widely read internationally. By this and other means, the US ways of performing basic research in management and business spread out over Europe and more recently into Asia. ${ }^{7}$ While the first language of the researchers is not always English, this non-US research is typically disseminated through US and other English language journals across the globe, more recently assisted by the spread of the internet.

In this article we set out the current situation for the location of business research by focusing on the written outputs of research programmes. We note that journals are not only significant foci for the dissemination of knowledge, but they also have a role in identifying the research agenda through editorials, invited contributions from leading thinkers and special issues. We take the research community's view of what is a good research output by using weighted citation outputs of published research material, avoiding judgements that result in 'narrow' journal lists. We show that there seems to be a global contest emerging among countries and institutions, and that the driver of the contest is the diffusion of knowledge about research and related research practices caused by the open US system that has increasingly become matched by the innovations of others, especially the Europeans. As a consequence, we suggest it is no longer necessary to be trained in the US to be 'world-class' in the increasingly global world. Moreover, globalisation does not eliminate the need to understand regional specificities for business: non-US schools have begun to exploit their proximity to globally excellent non-US companies and universities to create unique capabilities. We suggest that this challenge to the established US schools and their dominance has been overlooked or under-estimated by several important business commentators.

We also probe what these results mean for companies and students. We suggest that companies can go to a large number of European and Asian schools to source fundamental knowledge, and that the research of many of these schools is every bit as world class as that produced by the top US schools. 


\section{Measuring Business Knowledge Production}

Research in business schools has characteristics that are similar to that conducted in other social and natural sciences. Individuals and teams examine issues and problems they believe to be important, utilising a variety of techniques ranging from theory building and conceptual modelling to simulation and laboratory experiments, and other kinds of empirical work, including case studies, questionnaires of managers and utilisation of public and private archival data bases. It is widely accepted that such research is not valuable unless it is disseminated through scholarly mechanisms. ${ }^{8}$ This dissemination allows knowledge to be shared, and, more important, ideas to be reviewed and challenged by others in a way that identifies what is valid and allows the state of knowledge in the business field to move forward. Dissemination is the condition sine qua non for cumulativeness in science: as Newton said, 'If I have seen a little further it is by standing on the shoulders of giants. ${ }^{99}$

A key mechanism by which ideas are disseminated is the publication of outputs in scientific journals: they have transparent mechanisms for assessing knowledge based on the peer review system and a board of editors. In contrast, many book publishers have weaker review systems and (in the field of business) some contract authors to publish books before they have been reviewed: there are many magazines that also lack a peer review system. As the field of management has matured, so scientific journals have become more important. Most journals are widely accessible internationally via electronic databases (via university internal websites), and thus much more easily accessible than books. Although other kinds of knowledge diffusion - such as conferences, workshops and web-based non-peer-reviewed outlets such as SSRN - are gaining prestige, these can increasingly be seen as complementing rather than replacing scientific journal outputs. ${ }^{10}$

It is widely agreed among scholars that, at the aggregate level of a large institution or country, the production of knowledge can be measured by looking at scientific outputs in journals. ${ }^{11}$ Journals are where the community debates and exchanges ideas. However, which journals should be looked at, and how outputs should be counted are hotly debated topics, for there are several thousand journals even in the narrow field of management. Some cover a wide domain, seeking to move knowledge forward on a broad front, while others are more specialised, targeting specific topics and methods. In general the most prestigious journals cover a breadth 
of topics, but this is not always so, and some very prestigious journals are much narrower in scope. Many university deans and promotion committees have a favourite list of 'top quality relevant journals', counting only the outputs of their faculty that are published these journals. This list is used to decide the pay and the future (especially tenure) of faculty. ${ }^{12}$ In recent years there has been a trend to define such lists (usually referred to as the list of 'A journals') in a narrow manner and to be very dogmatic about which publications 'count' (and are on the list) and which don't (and thus are not). By their inflexible attitudes, deans and promotion committees risk under-valuing debates in specialised communities, giving scholars incentives to conform to the existing state of science rather than thinking more widely, and imposing unnecessary (and possibly dangerous) limits on any discourse that might challenge existing paradigms. ${ }^{13}$ In contrast to this trend, accreditation bodies outside the USA (such as HEFCE in the UK, EQUIS in Europe and the public system of evaluation of universities and research institutes in the Netherlands) have rejected narrow lists as a way of assessing quality, a stance which has gained the support of the scientists undertaking the research. There are many journals with high citation scores (and with giant articles that have moved whole fields of thinking) that are not on these 'A-lists'. Starbuck has looked closely at the operation of the journal system and shown convincingly that in management it is impossible to define the comparative value of knowledge by reference to such simple lists. Even the most prestigious management journals are not perfect in their ability to identify valuable and valid findings, especially when the findings challenge norms, and using only a limited range of journals risks closing off access to (perhaps valuable new) ideas that may appear first in unfashionable titles. ${ }^{14}$

We are keen to avoid a measurement regime whose legitimacy is not clearly aligned with the assessing of research in an un-biased manner. ${ }^{15}$ As Durand and McGuire point out, legitimacy is critical in this arena, and bodies such as Deans of Schools - and even trade associations such as AACSB - have potentially conflicting interests. ${ }^{16}$ We therefore propose a research assessment method based on citations, which is the 'democratic' vote of the scientific community as evidenced by their propensity to recognise formally and openly the importance of other researchers' work. Our approach is in common with widely accepted practices in other fields: the logic is simple, in that more important articles get cited more often, while those of less importance are cited less, or not cited at all. ${ }^{17}$ The research question that drives 
our article is:

Which countries and institutions are producing influential basic research in management?

\section{Methods}

A digression is necessary to appreciate our solution to the computational challenge. In the fields of business and management, ideas have a long half-life. It is therefore not possible to obtain a clear picture of citation scores for individual articles until some years have passed, but a very good approximation to future citations can be obtained by looking at the current citation rate of the journal in which the piece is published. ${ }^{18}$ According to scholars who have used ISI-SSCI, journals listed in the Journal of Citation Report constitute a good proxy to analyse the evolution of the field. ${ }^{19}$ In our field, most of the citations that occur in business and management are confined to a list of some 149 journals, a figure which (while it is far less than the total journal population) is nevertheless much larger than most business school deans are willing to accept, and also larger than is used, for instance, by the Financial Times and University of Dallas, whose rankings are based on much more limited journal lists. Our approach has therefore been to use the widest definition of business and management journals to obtain a meaningful picture of basic research, and then to weight each university’s outputs by the citation score of the journal. This method essentially produces a forecast of likely outcomes: pieces that are likely to be more important will be weighted more highly than those likely to be less significant (but none the less relevant in some domain). One or two journals in the field have rapidly changing citation scores, but in the vast majority of cases scores remain extremely stable, indicating that, while this method of forecasting might need occasional adjustment for micro-level analysis, for our purpose the approach is robust. Our weighting system is also consistent with the findings of scholars in the field of management who have examined such matters retrospectively over long periods. ${ }^{20}$

We collected data for all the articles published in all the journals on the Thompson ISI database from 1992 to 2005, and coded them by institutional affiliation and country. The enabled us to identify 65,480 articles published in 149 journals by 58,418 different authors belonging to 8,040 different institutions worldwide: the scale of this database is probably 10 times larger than has been used in any previously 
published ranking exercise. (Details of our methods are explained in the Appendix.)

Most ranking tables look backwards, and take averages over several years, giving a very historical view of the location of scholarly output. Work is constantly in the pipeline; research takes time to publish, and most pieces are published at least a year after they are written. We believe that examining the present and using past information to project forward is a preferable method of analysis.

This article focuses on four indicators of performance. We first position our countries and universities based on their outputs in 2005, to provide a relatively recent base line. We next look at how fast things are changing, and in which direction, by examining trends over the previous 14 years (1992-2005), and we report the Trend line and the Standard Error of the estimate that indicates the reliability of the trend (a higher number meaning a less reliable forecast). ${ }^{21}$ Whilst this method of forecasting may seem simple - even crude - as it does not take account of the fact that individual researchers may change institutions, the short time frame of available data and the 'lumpy' nature of research outputs makes any other forecasting method risky. Indeed, because any single year's positional ranking may be subject to outside disturbance and be not properly representative, we also compute the likely position of a school university based on past trends, and report the likely position of the institution last year as the 2006 Forecast. The difference between 2006 Forecast and the 2005 share, taken together with the Trend, gives some idea of potential errors in the 2005 data, and thus a more accurate feeling for the school's position. Finally, because the volume of research is increasing all the time, we look at world market shares (computed annually), rather than raw counts of articles.

\section{US Dominance and the Challenge from Europe and Asia}

We first rank countries. Exhibit 1 and Table 1 show that the US has dominated the world production of research in management, but that this position is being contested. The US market share, $83 \%$ in 1992, had dropped to $60.4 \%$ by 2005 , and is forecast to continue to fall at a rate of $1.5 \%$ a year (se 0.135 ). Based on these extremely stable trends, the USA will account for less than 50\% of world output by the end of 2010 . 
Figure 1: USA vs. Europe, Asia, Canada and Rest of the World

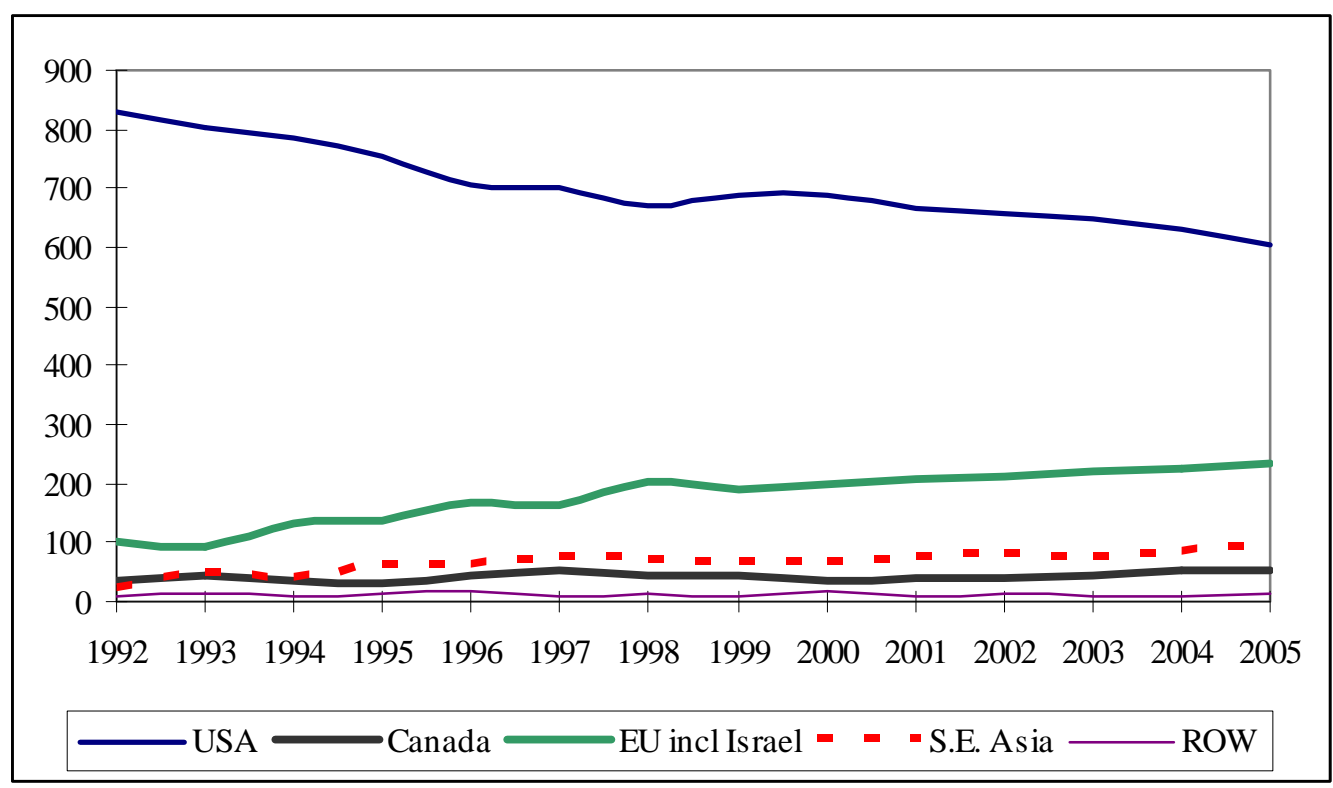

Notes: Share Figures are parts per '000

Table 1: Country Shares at end of text

Where is the challenge located? Canada is avoiding the decline of the USA, but is not contesting, with a share of 5\% in 2005 and a negligible rate of growth of less than $0.1 \%$ a year. Europe is the major source of competition: its world share has grown from $10.3 \%$ in 1992 to $23.5 \%$ in 2005 and its rate of growth is 1\% (se 0.1). Another growth centre is South East Asia, which had reached a market share of nearly $10 \%$ by 2005 and, growing at $0.4 \%$ a year, is likely to prove a formidable contestant.

Which countries are the sources of this growth energy? In Europe Great Britain is a very important focus, with a share that has doubled from $4.1 \%$ to $8.1 \%$ during the period, and a growth rate (at $0.3 \%$ a year) that, if sustained, will give it a world share of $10 \%$ by 2010 . Elsewhere in Europe, the Netherlands represents the second major driving force: with 3.4\% of the world share in 2005 and a growth rate of $0.18 \%$ a year it will reach a 5\% world share by the end of 2010. Germany, France and Spain each have less than $2 \%$ of the world market and slower rates of growth.

The challenge from the Far East is strong. Australia has increased its position to 5th in the world. China is, of course, rising in significance, although most current Chinese research comes from the Hong Kong province. Taiwan and Singapore are other important locations, while Korea is also moving up, more slowly. However 
despite its wealth, Japan is lagging behind, as if reluctant to accept international standards of research.

\section{The Declining Dominance of US Schools}

Is the dominance of a few countries mirrored by the dominance of a few institutions? Surprisingly, this is not the case. Whilst our figures confirm what is well known - that Wharton (University of Pennsylvania) and Harvard are still the world leaders in the production of knowledge in the sphere of management, having held the top two positions in every year since 1992 (with the single exception of 1996) - what is less well appreciated is that their market shares have declined dramatically: while they still lead the world scene, they no longer dominate it. This is not to belittle their impact on knowledge: Wharton alone at one time had 2.2\% of the world's output, and still has $1.4 \%$ - more than the total output of whole countries such as Spain, Italy and Belgium. But the downward trend is clear, with their share falling by about $0.1 \%$ a year (a statistically significant trend). Harvard's share has also fallen across the period, from $1.8 \%$ to $1.3 \%$. While its long-term trend is unclear, showing several local peaks, the overall trend over the last 6 years shows a clear decline.

Table 2 tracks the world rankings of the top schools, showing world, US and Rest of World rankings, together with their respective shares and growth rates (in parts per thousand). The cut off point for entry into our table is $0.1 \%$ global share (equivalent to the output of about 10 active researchers); we consider that an institution performing below this level cannot be called internationally active in research. The world of management research is concentrated among a minority of the total universe of universities, but the club is quite large. Moreover, within this club the production of research is quite well dispersed among many well known, and some less well known, institutions. Our data suggests that there are slightly more than 200 internationally active research institutions (i.e. only $2.5 \%$ of the 8,000 institutions that undertake research) that collectively account for $70 \%$ of the world's output.

\section{Table 2 Institutional shares and trends at end of text}

Looking within the data, we see some clear trends that indicate the decreasing global impact of US schools. Compared with 1992, most US schools have stood still, 
a few have slipped down the rankings at a significant rate, while the market shares only two of the top 40 US schools (Maryland and Emory) have risen at a statistically significant rate, and even then at less than $0.03 \%$ a year ( 0.3 parts per thousand).

In contrast, there are four rising stars from Europe that are contesting the US universities’ domination: London Business School (UK), INSEAD (France), Erasmus Rotterdam and Tilburg (both the Netherlands). Based on their current position and forecasted positions, their individual market shares are around 0.8\% (8 points per thousand), all of which are rising by between 0.03 and $0.05 \%$ a year, and the trends look extremely robust. This means that, by 2010, some (if not all) of these four could reach the $1 \%$ market shares of the world's top 10 institutions. Slightly further down the list (but still in the top 50) are three Canadian institutions, two Asian schools and another British school all of which have strong growth rates: Toronto, British Columbia and Western Ontario in Canada, Nottingham (UK), and the National University of Singapore and Australia's University of New South Wales, all of which are doing well by US standards, but have some way to go before they can challenge the leaders. It is worth noting a few major discrepancies between the actual position for 2005 and our 2006 forecast positions, on account of variable year to year research outputs at the institutional level, which mean that some schools are not listed in the top 50 that perhaps should be there: these include the Chinese University of Hong Kong (big gap between actual 3.10 and forecast figure of 4.58 parts per thousand) and Warwick University (registering actual and forecast figures of 2.38 and 4.04). Further down the list, there are also some quite well known universities whose management schools do not even make it into the top list because they are unable to meet our minimum requirement of $0.1 \%$ world share for 2005 , sometimes because their output fluctuates too much from year to year. ${ }^{22}$

The table also compares our results with those produced by two other oftenquoted rankings - from the Financial Times and the University of Dallas. Both of these rely on relatively narrow lists of journals that are strongly oriented towards US authors. The result of this narrowness can be clearly seen from the tables. Their rankings of the leading US institutions follow closely with each other, and with our results, but both systems are significantly adrift from our results when measuring the performance of non-US schools. In fact these rankings significantly underestimate their performance, and we suggest that these errors are serious, and give a misleading impression of the real academic achievements of schools outside North America in 
the field of basic scientific research.

\section{Drivers of Change}

What has driven these changes? To understand the answer to this question, we need to go back in time. The field of research in management as we know it today did not exist in the 1960s, when the US model of the scientific production of knowledge in the field of management first emerged, following an influential report from Gordon and Howell. ${ }^{23}$ They declared that management research was in dire straights, noting there were only 24 US schools giving about $100 \mathrm{PhDs}$ a year in the 1950s, and that much research was anecdotal and not scientific by the standards of that time. This report triggered massive funding, starting in the 1960s, directed at improving the research training of US academics in business schools and shifting research towards Social Science methodology (see AACSB 2007 report). As a result the number of $\mathrm{PhDs}$ and programmes grew, and a clear style of training and research working emerged at the top schools, based on formal course work, with examinations as well as the production of theses and academic articles. New journals were founded to publish scientifically rigorous work, typically with editors that were serious 'heavy league' scholars from the same schools that ran the $\mathrm{PhD}$ programmes. These journals' boards, and those involved in the PhD programmes in the top institutions, changed only slowly over time, demonstrating the power of the newly established norms.

The US model also extended into teaching methods, with the adoption of standardised courses and curriculum for undergraduate business studies and postgraduate professionally oriented qualifications (typically MBA). The standardisation was reinforced by tenure systems that emphasised $\mathrm{PhD}$ qualifications and research effectiveness, by accreditation bodies such as AACSB and by the departmental academic peer review system adopted by many major US universities.

The policies of US national institutions and top US universities were clearly critical in leading to the US domination of the world of management research into the 1990s, and still have important influence today. But why is the research now so widely dispersed among institutions, and what has caused the recent strong growth from outside the US? It is important to realise that, from the first, the top US schools such as University of Pennsylvania have operated an 'open door' system. They trained far more doctoral students than they could hope to use, and in many cases they 
have implemented a policy of increasing their genetic pool of faculty by not hiring their own graduates, but rather going to other leading schools in a purposeful crossfertilisation exercise. This cross fertilisation was further reinforced by the arduous tenure system, that meant that top schools were not only pushing out PhDs but also junior faculty (who had received further research training) allowing other US institutions to hire good researchers. These practices made it hard for any single US institution to monopolise the production of research. The data reinforces the sense that competition has been fierce between the top US institutions, and has not resulted in any single player or small group achieving dominance: rather excellence has been spread among more than 100 universities (see Table 2).

The exceptional welcoming policy of the top US schools also helped other countries learn the US system. Top US universities were happy to train non-US scholars, and often gave them scholarships for PhD study. While some remained in the USA, many went back to their home countries, taking with them not just the skills of undertaking research but also knowledge of the US training programmes and US systems that supported basic research. At the same time, some major European Schools (particularly London Business School and INSEAD) made a policy of hiring US trained faculty (both Americans interested in travel and returning second generation nationals) and paying the higher salaries demanded by these US graduates (which could often be more than double what was offered to those with local doctorates). Clearly, such policies further contributed to the diffusion of the dominant US design.

The generosity of the US system was not enough, in itself, to change entrenched national practices and attitudes in Asia and Europe: local institutions had to change too. In Europe, the UK and the Netherlands have used national policies to foster internationally oriented research, each undertaking regular national audits to assess the state of research and publicise the results. In both counties, money has been tied to results, giving universities a very strong incentive to change and adopt more internationally oriented research systems. In the UK, the policies were introduced with a struggle, but were quickly adjusted to give very substantial incentives to those universities that performed well internationally, amounting to as much as \$50,000 per faculty member per year. National policies in countries such as Australia and Singapore have also shifted to foster international level of research. In contrast, despite their large economic endowments, countries like France, Germany, Spain, 
Italy and Japan are moving more slowly, because the ethos of universities involved in management teaching in these countries still does not favour internationally benchmarked research.

It is important to realize that the national policies of the UK and the Netherlands also encouraged a new form of competition, which challenged the dominant international paradigm. Some schools in these countries, while recognising the superiority of the US system, did not hire US trained faculty on the same scale as London Business School or INSEAD, but rather sought to form alliances with US schools. Senior US faculty visited their institutions, which then copied the US training systems and promotion systems selectively, often modifying them to fit local needs and on occasions to create improvements. Institutions such as the Economic and Social Research Council in the UK and KNAW (the Royal Netherlands Academy of Arts and Sciences) have provided additional support for this line of development. This differential but parallel track seems to have been extremely successful in the case of UK institutions such as Nottingham and Warwick and the Dutch Universities of Erasmus and Tilburg. These schools have a much smaller resource base than the top US schools, and have approached the basic research paradigm with a greater sense of eclecticism, and valued a wider range of methods. In turn, some of these methods have been adopted completely by the US mainstream (for instance the work of Pettigrew from Warwick University on the processes of management).

\section{Discussion}

We have noted how, in the mid-20 $0^{\text {th }}$ century, the US established a new paradigm for research with massive institutional support, resulting in their domination of the world research scene in management in the 1980s and 1990s. Our analysis shows that, measured by the research outputs in scientific journals, US dominance has been slipping, and that its market share seems likely to halve between 1990 and 2010 . Meanwhile a number of European and Asian countries have emerged that are engaged in the basic research endeavour, and are producing outputs at an international level that contest those from the US. We now discuss how we can stand back and better understand what is happening by looking at previous research on industry evolution.

The two parallel development paths of emulation and adaptation of the dominant US paradigm in the Business Research industry parallels the classic models 
of industry development that have been observed in other industries. ${ }^{24}$ Industry Life Cycle theorists argue that industries display successive well defined development phases. The initial phase is characterised by a few institutions that define the norms and set the product standards. In the academic research industry, the norms were around knowledge production and diffusion, PhD programs and journals were created, and a community emerged with strong professional attitudes. The next phase of industry development typically involves the diffusion of the model and the emergence of a dominant design. ${ }^{25}$ This diffusion occurred within the US and Canada (as the data clearly shows) and was promoted by the open institutional arrangements of the top US research schools and reinforced by AACSB. At this time, the model began to diffuse internationally, with the appearance of two European Schools (London Business School and INSEAD) that copied the US model. ${ }^{26}$

The theorists argue that in the final phase, as an industry matures, the global dominant standard ceases to be just copied, and diffusion is accompanied by significant local adaptations. This is also the period when new business models emerge to challenge the traditional order. The academic setting of business schools can now, we suggest, be seen as being in this third phase. Just as businesses are becoming more global in scope, but also more sophisticated in adapting to local needs, so too are business schools and the education agenda they undertake. A new class of global businesses and managers are emerging that need top ranked universities that are closer to the markets they serve.

Whilst our data are not presented in this manner, our reading of the world of research indicates a parallel trend. Managerial knowledge has been expanded, business problems have become more complex and research agendas more sophisticated and more specialised. Universities and academic institutions are specialising and developing excellence in local niches, such as the management of public bodies, of local innovation clusters or of sustainable development. The ways in which different notions are adapted to different contexts and implemented in different firms require researchers and teachers to match generic knowledge and in-depth information onto local contexts. In a similar manner, geographic specificities encourage the emergence of research programmes which bridge cultural gaps and adapt knowledge production to specific contexts. In parallel, there is a rise in the number of journals that deal with international problems, that publish studies using non-US and, increasingly, multi-country data, and that recognise new non-US based 
methods. Finally, we note that the rise of the internet has opened up the possibility of a new system of research taking hold in the next decade or so: new ways of undertaking peer reviews are emerging along with new ways of conducting research.

The reader should recognise the limitations of our research. Journal citation counts are just one way by which academics 'vote' on the value of research outputs, and new databases (such as Google Scholar) are emerging that permit a more comprehensive counting procedure. Of course knowledge is far more than the production of journal outputs, and at best we are tracing a proxy for research activity. We leave it to others to undertake a more comprehensive analysis of the global institutions involved in the production of knowledge. We also caution that our data may understate the real shifts. Just as changes in industry sales and market share are proxies for changing company health in the corporate sector, so too changes in journal output and market shares are signalling the rise of non-US schools into the arena of top quality research. The change in the structure of outputs, we argue, may signal a much more fundamental change in the way that research is carried out. And, in this case just as in other industries, changing in outputs may lag rather than lead true competitive positions. There are long lags in the system of producing research, and if conferences of today signal publications for tomorrow, the frequency with which nonUS scholars capture a significant share of top US and international conference papers and prizes reinforces our suggestion that fundamental changes are taking place.

\section{Relevance to Businesses}

What are businesses to make of this? How does basic research help them? It is widely recognised that basic research does not translate easily into current practice, and whether we are talking of physics, life sciences, economics or management, there is a always a gap between laboratory and application. This translation problem has given rise to much soul searching in business schools and the journal community. There is a challenge to translate knowledge in research into the knowledge for the classroom, and there is an even bigger challenge in making journals accessible to practitioners when their ideas may have the potential for immediate application (see for instance AACSB, 2007).

There are 4 top quality academic journals in our list which have as their objective both originality in what is published and accessibility for the practitioner audience: Harvard Business Review, Sloan Management Review, California 
Management Review and Long Range Planning. ${ }^{27}$ We have not engaged in a 'practice' survey to verify whether the claim of accessibility to the wide audience is achieved, and we fully recognise that much of practice relevance is published outside these journals. However, these journals have clear policies of targeting the dual audience that are recognised within academia, and they rank well in the academic stakes as being among the top $20 \%$ of all journals in terms of citation scores (see Appendix). They are also used in the classroom to communicate the latest ideas and supplement standard texts, and their high download numbers give evidence that they are widely read by consultants and thinkers in management practice. They provide a conduit for communication between academic and managerial communities. These outlets specialise in describing situations that managers encounter in their working lives, and elaborate new theories and new frames that they may find useful and which have validated using scientific methods.

We note in passing that three of these publications are oriented largely towards the US, having nearly $90 \%$ of their contributions from North America (see Table 3). The internationalisation of these journals seems to be proceeding at a slower pace than the mainstream. By contrast, Long Range Planning has a more balanced international input, with many contributions from Europe and Asia, and often reports on non-US contexts with new framing that is highly relevant to international executives and policy makers.

Table 3: Author Location in Practice Oriented Academic Journals

\begin{tabular}{|c|c|c|c|c|c|c|c|c|c|c|}
\hline \multirow{3}{*}{$\begin{array}{l}\text { Author location } \\
\text { USA+ Canada }\end{array}$} & \multicolumn{2}{|c|}{$\begin{array}{l}\text { Harvard } \\
\text { Bus. Rev. }\end{array}$} & \multicolumn{2}{|c|}{$\begin{array}{l}\text { California } \\
\text { Mgt. Review }\end{array}$} & \multicolumn{2}{|c|}{$\begin{array}{l}\text { Sloan } \\
\text { Mgt. Rev. }\end{array}$} & \multicolumn{2}{|c|}{$\begin{array}{l}\text { Long } \\
\text { Range Plan. }\end{array}$} & \multicolumn{2}{|l|}{ Total } \\
\hline & 1062 & $(88 \%$ & 359 & $(84 \%$ & 397 & (75\% & 204 & (34\% & 2022 & (73\% \\
\hline & & & & & & & & ) & & \\
\hline Europe & 123 & $(10 \%$ & 50 & $(12 \%$ & 115 & $(22 \%$ & 342 & (56\% & 630 & $(23 \%$ \\
\hline & & ) & & ) & & ) & & ) & & \\
\hline Asia & 20 & (2\%) & 11 & (2\%) & 14 & (3\%) & 56 & (9\%) & 101 & $(4 \%)$ \\
\hline Others & 3 & & 5 & (1\%) & 2 & & 5 & (1\%) & 15 & \\
\hline Total & 1208 & & 425 & & 528 & & 607 & & 2768 & \\
\hline
\end{tabular}

(C) In table and data V. Mangematin \& C. Baden - Fuller, 2007 reproduced under licence

\section{Conclusions}

This article has examined the results of the intertwining between two key groups of institutions that organise scientific research in the field of management. One group 
(mainly university departments) is dedicated to the production of knowledge and is where scholars work; the other is where they exchange of ideas, and is dedicated to the discussion of research results and the definition-recognition of the research agenda. The latter group is centrally defined by journals and their editorial boards and review networks. Our analysis (based on a weighted count of publications in journals that are likely to be cited by future generations of researchers) shows how this intertwining has been changing over recent years, with particular reference to the institutions that produce knowledge.

US universities have established the field of basic research in management as we know it today, and US scholars have been deeply involved in professional associations, journal creation and journal management. Their central position both enhances their reputation and has been self-reinforcing. Our analysis of the journal outputs of research programmes of the last 13 years suggests that, although the US is still the leading management research nation, its position is declining steadily, and other regions are emerging. There is particular strength in Canada, the UK, Netherlands, Australia and selective parts of Asia.

Our data also shows that this is not an industry dominated by one or two institutions, but rather research is concentrated among perhaps a few hundred universities and research institutes world-wide. In this set, the US universities have quite stable positions (defined by market share of journal outputs) with respect to each other, but not with respect to non-US institutions. Some European and Asian institutions are emerging rapidly as important actors, and creating new regional centres, with new data, new methods and new ideas. This is creating a new conversation among the research community, and new opportunities for scholars involved in teaching and research.

Our findings have important implications for policy makers and businesses. Our data suggest that European and Asian students, businesses and policy makers need no longer travel to the US for dialogue with groups of the best academics: in fact many top quality research institutions now lie outside the US. While have identified some of the more prominent and established institutions in our lists, of course we recognise that there are top thinkers and excellent researchers at other institutions not listed here. 
Vincent Managematin is Research Professor at the Grenoble Ecole Management and UMR GAEL (INRA/UPMF) in France. He is an acknowledged expert on the biotechnology and nanotechnology industries, and his research stands at the intersection of Strategic Management, Management of Knowledge and Innovation. He is an active member of the European research community, with experience in fund raising and management of research grants, and has published more than 30 papers in leading journals, as well as sitting on the editorial boards of Organization Studies and Long Range Planning. Université Pierre Mendès, 38040 Grenoble Cedex 9 France tel + 33476825686 e-mailvincent@grenoble.inra.fr

Charles Baden-Fuller is Centenary Professor of Strategy at Cass Business School, City University and Editor-in-Chief of LRP: Long Range Planning. He has published extensively in the academic and business press on the subject of transformation of mature organisations, managerial cognition, entrepreneurship, networked firms and knowledge management. Funded by UK and EU grants, his research group is currently working on how young companies can integrate science, artistic creativity and management in the technology industries, with a special emphasis on the role of advisors and boards of directors. He is a visiting scholar at the Wharton School and a regular advisor to companies internationally. Cass Business School, City University, London EC1Y 8TZ tel: +44 (0) 2070408652 e-mail: c.baden-fuller@city.ac.uk 


\section{Appendix}

\section{Methods}

Our database includes 65,480 articles published in 149 journals by 58,418 different authors around the world between 1992 and 2005. The journals (see table below) were selected on the basis that they were listed in Thompson's Journal Citation Reports (JCR) in the fields of Business, Business - Finance, Management and Public Administration, and more than half of the journals we identified belong to more than one category (mean 1.6). Two publications were excluded: Fortune Magazine (which is not a peer reviewed academic publication) and Betriebswirtzschaft (which does not have English text, and is therefore not easily accessible to scholars world-wide). Because the JCR lists all the major journals in the broad field of management, along with about $80 \%$ of all other journals of any significance, our coverage of scientific journal papers is probably over $90 \%$.

For each journal we identify all papers and their authors, together with all the authors' institutional affiliations. If a journal was not in the list for a particular year, we did not count the articles published in that journal in that year. No institution can score more than once per paper, and each listed institution is given equal merit. (Checking a sub-sample revealed that partial weighting made no significant difference to the results.) Institutions are classified by parent organisation (typically a university, a research institution or even a firm), and we identified more than 8,040 such organisations world wide. This method means that institutions with several departments producing management research (such as London School of Economics or Erasmus University Rotterdam) are identified as single entities. We also assigned institutions to countries (assigning the only multicountry institution - INSEAD -to France).

We weight each journal entry by the Thomson Citation Score for the relevant journal in the relevant year (with the most recent weights listed in the table below). Our weighting system means that a piece in a prestigous journal (which is more likely to make a significant scientific impact) is counted more heavily than one published in a minor journal, which has less chance of making an impact. The table shows that most prestiguous journals as having a JCR score of between 1.0 and 4.0, almost 10 
times that of minor journals.

The final result gives a picture of the publication outputs for each institution (or country) for each year on this weighted basis. We checked the whole of our results by removing the weighting system, and found - as we expected - a close correlation between the lists. We have also checked to see if different author weightings would cause the results to differ much, and they did not.

\section{Note on Impact Factors}

Impact factors are calculated each year by Thomson Scientific and are published six months later in the JCR. To see how they are calculated, we give an example for the JCR Impact factors for 2005. If:

$A=$ the number of times articles published in the chosen journal in the two years 2003 and 2004 were cited in the all 1700 indexed journals (regardless of field) in the Thomson database during the year 2005; and $B=$ the number of 'citable items' (that is proper articles, not editorials and letters-to-the-Editor) published in the chosen journal in the two years 2003 and 2004;

The 2005 JCR impact factor $=A / B$

The appendix Table presents the list of journals with their JCR categories, ranked by their 2005 Impact Factor (IF2005), as well as the total number of citations received by each journal (TC2005). Major journals and interdisciplinary journals receive the highest number of citations, as the knowledge they disseminate is generic enough to spill over on other disciplines.

\section{Appendix Table at end of text}


Table 1: Country Shares

\begin{tabular}{|c|c|c|c|c|c|}
\hline Country & $\begin{array}{l}1992 \\
\text { Share }\end{array}$ & $\begin{array}{l}2005 \\
\text { Share }\end{array}$ & $\begin{array}{c}\text { Forecast } \\
\text { Share } 2006\end{array}$ & Growth Rate & S. Error \\
\hline USA & 830 & 605.7 & 603.0 & -15.17 & 1.35 \\
\hline UK & 41.4 & 80.7 & 96.7 & 3.20 & 0.77 \\
\hline Canada & 35.2 & 50.8 & 44.7 & 0.68 & 0.40 \\
\hline Netherlands & 7.2 & 33.8 & 32.1 & 1.82 & 0.20 \\
\hline Australia & 5.7 & 25.7 & 25.0 & 1.16 & 0.25 \\
\hline Pr China & 2.4 & 21.0 & 27.4 & 1.26 & 0.31 \\
\hline France & 9.5 & 19.9 & 20.9 & 0.69 & 0.14 \\
\hline Germany & 4.0 & 17.8 & 16.4 & 1.03 & 0.12 \\
\hline Spain & 5.5 & 13.1 & 11.5 & 0.80 & 0.11 \\
\hline Taiwan & 1.4 & 13.0 & 6.7 & 0.54 & 0.13 \\
\hline Singapore & 0.6 & 11.6 & 9.8 & 0.72 & 0.11 \\
\hline South Korea & 2.5 & 10.0 & 9.1 & 0.38 & 0.12 \\
\hline Belgium & 7.9 & 9.1 & 6.1 & 0.19 & 0.12 \\
\hline Sweden & 0.8 & 9.0 & 11.2 & 0.53 & 0.12 \\
\hline Italy & 3.6 & 8.4 & 11.6 & 0.51 & 0.11 \\
\hline Israel & 10.6 & 7.7 & 9.9 & -0.11 & 0.20 \\
\hline New Zealand & 2.1 & 7.6 & 6.3 & 0.29 & 0.12 \\
\hline Switzerland & 2.1 & 7.1 & 5.8 & 0.37 & 0.07 \\
\hline Denmark & 2.3 & 5.7 & 5.7 & 0.34 & 0.06 \\
\hline Japan & 2.8 & 5.0 & 5.4 & -0.03 & 0.14 \\
\hline Norway & 0.9 & 4.8 & 5.4 & 0.24 & 0.07 \\
\hline Finland & 4.4 & 4.4 & 4.8 & 0.13 & 0.07 \\
\hline Austria & 0.5 & 4.3 & 2.9 & 0.21 & 0.05 \\
\hline Turkey & 0.2 & 3.3 & 2.4 & 0.20 & 0.03 \\
\hline Greece & 0.8 & 2.9 & 2.0 & 0.08 & 0.08 \\
\hline India & 3.0 & 2.4 & 1.8 & -0.13 & 0.08 \\
\hline Ireland & 0.8 & 2.0 & 1.6 & 0.01 & 0.05 \\
\hline Brazil & 0.1 & 1.9 & 1.8 & 0.10 & 0.04 \\
\hline Portugal & 1.2 & 1.8 & 2.0 & 0.09 & 0.05 \\
\hline Chile & 1.2 & 1.0 & 0.9 & -0.02 & 0.04 \\
\hline
\end{tabular}

Share Figures are parts per '000

Growth rates and Forecasts are based on trend data from 1992 to 2005

(C) In table and data V. Mangematin \& C. Baden - Fuller, 2007 reproduced under licence 
Table 2 The World's Top Schools

\begin{tabular}{|c|c|c|c|c|c|c|c|c|c|c|}
\hline SCHOOL & $\begin{array}{l}\text { World } \\
\text { Rank } \\
2005 \\
\end{array}$ & $\begin{array}{c}\text { US } \\
\text { Rank } \\
2005 \\
\end{array}$ & $\begin{array}{l}\text { RoW } \\
\text { Rank }\end{array}$ & $\begin{array}{c}\text { Share } \\
2005\end{array}$ & $\begin{array}{l}\text { Growth } \\
92-05\end{array}$ & $\begin{array}{c}\text { Forecast } \\
2006\end{array}$ & $\begin{array}{l}\text { Std } \\
\text { Error }\end{array}$ & $\begin{array}{c}\text { Forecast } \\
\text { Rank } \\
2006 \\
\end{array}$ & $\begin{array}{c}\text { FT } \\
\text { Rank } \\
2006 \\
\end{array}$ & $\begin{array}{c}\text { Dallas } \\
\text { Rank } \\
2006 \\
\end{array}$ \\
\hline USA - Univ. Penn & 1 & 1 & & 14.05 & -0.66 & 13.50 & 0.20 & 2 & 2 & 1 \\
\hline USA - Harvard Univ. & 2 & 2 & & 13.81 & 0.13 & 19.83 & 0.34 & 1 & 1 & 3 \\
\hline USA - Univ. Michigan Ann Arbor & 3 & 3 & & 11.75 & -0.53 & 10.25 & 0.15 & 5 & $14=$ & 9 \\
\hline USA - Stanford Univ. & 4 & 4 & & 10.92 & 0.00 & 11.42 & 0.20 & 4 & 4 & 11 \\
\hline USA - Duke Univ. & 5 & 5 & & 10.75 & 0.16 & 9.49 & 0.10 & 7 & 7 & 5 \\
\hline USA - New York Univ. & 6 & 6 & & 10.70 & 0.12 & 12.49 & 0.17 & 3 & $8=$ & 2 \\
\hline USA - Natl Bur Econ Res & 7 & 7 & & 10.62 & -0.30 & 8.97 & 0.20 & 10 & & \\
\hline USA - Univ. Texas Austiin & 8 & 8 & & 9.77 & -0.69 & 7.06 & 0.22 & 23 & 19 & 10 \\
\hline USA - Univ. Chicago & 9 & 9 & & 9.72 & 0.01 & 8.93 & 0.17 & 13 & 3 & 4 \\
\hline USA - Northwestern Univ. & 10 & 10 & & 9.26 & -0.49 & 7.55 & 0.13 & 20 & 13 & 12 \\
\hline USA - Univ. Maryland Coll. Pk & 11 & 11 & & 9.25 & 0.23 & 8.95 & 0.10 & 11 & $5=$ & 7 \\
\hline USA - Univ. Minnesota & 12 & 12 & & 9.25 & -0.24 & 7.69 & 0.14 & 18 & $23=$ & 16 \\
\hline USA - Univ. So Calif & 13 & 13 & & 8.91 & -0.10 & 8.94 & 0.12 & 12 & $20=$ & 15 \\
\hline USA - Texas A\&M Univ. & 14 & 14 & & 8.87 & -0.14 & 6.27 & 0.09 & 29 & $37=$ & 44 \\
\hline USA - Indiana Univ. & 15 & 15 & & 8.71 & -0.41 & 6.19 & 0.18 & 31 & $37=$ & 23 \\
\hline USA - Columbia Univ., NY & 16 & 16 & & 8.54 & -0.30 & 9.38 & 0.11 & 8 & $5=$ & 8 \\
\hline UK - London Business Sch & 17 & & 1 & 8.29 & 0.39 & 8.48 & 0.18 & 16 & $11=$ & 24 \\
\hline Netherlands - Univ. Erasmus & 18 & & 2 & 8.26 & 0.49 & 7.40 & 0.07 & 22 & $81=$ & 80 \\
\hline USA - M.I.T. & 19 & 17 & & 8.10 & -0.14 & 9.53 & 0.18 & 6 & $14=$ & 6 \\
\hline USA - Univ. Calif Los Angeles & 20 & 18 & & 8.02 & 0.09 & 9.32 & 0.15 & 9 & 17 & 13 \\
\hline USA - Arizona State Univ. Tempe & 21 & 19 & & 8.01 & -0.12 & 5.90 & 0.10 & 34 & $35=$ & 33 \\
\hline USA - Cornell Univ. & 22 & 20 & & 7.78 & 0.03 & 8.11 & 0.19 & 17 & $23=$ & 34 \\
\hline USA - Univ. Calif Berkeley & 23 & 21 & & 7.43 & -0.41 & 6.53 & 0.20 & 28 & $8=$ & 31 \\
\hline USA - Penn State Univ. & 24 & 22 & & 7.24 & -0.16 & 7.44 & 0.14 & 21 & $23=$ & 17 \\
\hline France - INSEAD inc Singapore & 25 & & 3 & 6.66 & 0.32 & 8.66 & 0.08 & 14 & $11=$ & 14 \\
\hline USA - Ohio State Univ. & 26 & 23 & & 6.64 & -0.20 & 5.55 & 0.09 & 36 & $31=$ & 25 \\
\hline Netherlands - Univ. Tilburg & 27 & & 4 & 6.16 & 0.45 & 6.89 & 0.05 & 25 & & 55 \\
\hline USA - Univ. Illinois Urbana & 28 & 24 & & 5.96 & -0.56 & 4.85 & 0.22 & 42 & $31=$ & 21 \\
\hline Canada - Univ. Toronto & 29 & & 5 & 5.87 & 0.28 & 6.03 & 0.10 & 32 & $23=$ & 37 \\
\hline USA - Carnegie Mellon Univ. & 30 & 25 & & 5.82 & -0.10 & 5.80 & 0.14 & 35 & $31=$ & 27 \\
\hline USA - Michigan State Univ. & 31 & 26 & & 5.57 & 0.21 & 8.57 & 0.09 & 15 & $31=$ & 18 \\
\hline USA - Univ. Washington & 32 & 27 & & 5.56 & 0.14 & 7.61 & 0.17 & 19 & $20=$ & 22 \\
\hline Canada - Univ. Brit. Columbia & 33 & & 6 & 5.41 & -0.12 & 3.59 & 0.11 & 63 & $35=$ & 39 \\
\hline USA - Emory Univ. & 34 & 28 & & 5.38 & 0.31 & 6.61 & 0.09 & 27 & $20=$ & 20 \\
\hline USA - Rutgers State Univ. & 35 & 29 & & 5.23 & 0.05 & 6.03 & 0.13 & 33 & & 67 \\
\hline UK - Univ. Manchester & 36 & & 7 & 5.16 & 0.15 & 5.28 & 0.13 & 38 & $73=$ & \\
\hline Canada - Univ. West'n Ontario & 37 & & 8 & 5.02 & 0.11 & 4.58 & 0.09 & 48 & $23=$ & 50 \\
\hline USA - Georgia State Univ. & 38 & 30 & & 4.93 & -0.06 & 5.04 & 0.08 & 40 & & 48 \\
\hline USA - Univ. Wisconsin - Madison & 39 & 31 & & 4.75 & 0.06 & 6.23 & 0.13 & 30 & $37=$ & 32 \\
\hline USA - Univ. South Carolina & 40 & 32 & & 4.74 & -0.45 & 2.39 & 0.14 & 102 & $45=$ & 46 \\
\hline USA - CUNY Bernard M Baruch & 41 & 33 & & 4.73 & 0.08 & 3.83 & 0.07 & 57 & & $57=$ \\
\hline UK - Univ. Nottingham & 42 & & 9 & 4.69 & 0.30 & 4.74 & 0.05 & 45 & $73=$ & \\
\hline USA - Univ. Florida & 43 & 34 & & 4.67 & -0.11 & 4.80 & 0.11 & 44 & & 28 \\
\hline P R China - Hong Kong U.S.T. & 44 & & 10 & 4.61 & 0.19 & 6.94 & 0.16 & 24 & & 29 \\
\hline USA - Univ. Virginia & 45 & 35 & & 4.60 & 0.08 & 5.01 & 0.11 & 41 & $51=$ & $76=$ \\
\hline Singapore - Natl Univ. Singapore & 46 & & 11 & 4.59 & 0.30 & 5.48 & 0.09 & 37 & 70 & 52 \\
\hline USA - Georgia Inst. of Tech. & 47 & 36 & & 4.48 & 0.14 & 3.62 & 0.08 & 62 & $58=$ & 59 \\
\hline USA - Yale Univ. & 48 & 37 & & 4.44 & -0.05 & 4.35 & 0.12 & 51 & $23=$ & 42 \\
\hline Australia - N.S.W AGSM & 49 & & 12 & 4.41 & 0.16 & 3.88 & 0.06 & 56 & $51=$ & 70 \\
\hline USA - Boston College & 50 & 38 & & 4.40 & -0.12 & 3.06 & 0.11 & 80 & $47=$ & 47 \\
\hline USA - Miami Univ. & 51 & 39 & & 4.33 & 0.16 & 4.83 & 0.08 & 43 & $58=$ & 45 \\
\hline USA - Boston Univ. & 52 & 40 & & 4.28 & 0.03 & 4.41 & 0.07 & 50 & $47=$ & 49 \\
\hline USA - Univ. Connecticut & 53 & 41 & & 4.19 & 0.02 & 4.32 & 0.07 & 52 & & 60 \\
\hline USA - UNC at Chapel Hill & 54 & 42 & & 4.18 & -0.04 & 6.71 & 0.14 & 26 & $23=$ & 19 \\
\hline USA - Univ. Arizona Tucson Eller & 55 & 43 & & 4.15 & -0.29 & 2.91 & 0.11 & 83 & $47=$ & $57=$ \\
\hline
\end{tabular}




\begin{tabular}{|c|c|c|c|c|c|c|c|c|c|c|}
\hline USA - Indiana Purdue Indianapolis & 56 & 44 & & 4.04 & -0.01 & 5.18 & 0.08 & 39 & $41=$ & 30 \\
\hline UK - Oxford Univ. & 57 & & 13 & 3.91 & 0.21 & 4.49 & 0.06 & 49 & $51=$ & \\
\hline USA - Univ. Georgia Terry & 58 & 45 & & 3.85 & -0.22 & 3.83 & 0.10 & 58 & $62=$ & 73 \\
\hline USA - Univ. Pittsburgh & 59 & 46 & & 3.80 & -0.07 & 3.66 & 0.10 & 61 & $47=$ & 40 \\
\hline USA - Univ. Calif Irvine & 60 & 47 & & 3.78 & -0.07 & 3.39 & 0.10 & 66 & 18 & 36 \\
\hline Belgium - Catholic Louvain & 61 & & 14 & 3.77 & 0.11 & 3.10 & 0.08 & 79 & & \\
\hline USA - Univ. Notre Dame & 62 & 48 & & 3.68 & 0.18 & 4.71 & 0.08 & 46 & $37=$ & 38 \\
\hline Canada - Univ. M'treal \& HEC & 63 & & 15 & 3.65 & 0.11 & 3.68 & 0.04 & 60 & & \\
\hline USA - Louisiana State Univ. & 64 & 49 & & 3.33 & -0.31 & 1.39 & 0.11 & 171 & & \\
\hline Netherlands - Gronigen Univ. & 65 & & 16 & 3.32 & 0.15 & 3.38 & 0.03 & 67 & & \\
\hline USA - Dartmouth College & 66 & 50 & & 3.30 & 0.12 & 4.04 & 0.08 & 55 & $8=$ & 41 \\
\hline Canada - Concordia Univ. & 67 & & 17 & 3.24 & 0.07 & 2.09 & 0.05 & 119 & & \\
\hline USA - Vanderbilt Univ. & 68 & 51 & & 3.23 & -0.05 & 2.72 & 0.09 & 91 & $51=$ & $71=$ \\
\hline USA - Univ. Arkansas Fayetteville & 69 & 52 & & 3.22 & -0.06 & 1.73 & 0.09 & 145 & & 88 \\
\hline USA - George Washington Univ. & 70 & 53 & & 3.21 & 0.08 & 3.25 & 0.07 & 74 & $62=$ & 65 \\
\hline USA - Washington Univ. & 71 & 54 & & 3.21 & 0.15 & 4.24 & 0.05 & 53 & 16 & \\
\hline USA - SUNY Buffalo & 72 & 55 & & 3.20 & 0.04 & 2.40 & 0.10 & 101 & & $86=$ \\
\hline USA - Case Western Res. Univ. & 73 & 56 & & 3.18 & -0.03 & 3.50 & 0.06 & 64 & $58=$ & 54 \\
\hline P R China - Chinese Univ. H.K. & 74 & & 18 & 3.10 & 0.18 & 4.58 & 0.09 & 47 & & $78=$ \\
\hline UK - Ctr Econ Policy Res & 75 & & 19 & 3.10 & 0.10 & 2.75 & 0.10 & 89 & & \\
\hline USA - Fed Reserve Bank & 76 & 57 & & 3.04 & -0.22 & 3.27 & 0.19 & 73 & & \\
\hline Canada - Univ. Alberta & 77 & & 20 & 3.00 & 0.01 & 2.93 & 0.08 & 81 & & $78=$ \\
\hline USA - Syracuse Univ. & 78 & 58 & & 2.99 & -0.10 & 2.10 & 0.06 & 118 & & \\
\hline Netherlands - Maastricht & 79 & & 21 & 2.98 & 0.26 & 3.42 & 0.05 & 65 & & \\
\hline P R China. - City Univ. H. Kong & 80 & & 22 & 2.97 & 0.20 & 3.73 & 0.06 & 59 & & 98 \\
\hline USA - Florida State Univ. & 81 & 59 & & 2.96 & 0.03 & 3.21 & 0.05 & 75 & & $91=$ \\
\hline Australia - Univ. Melbourne & 82 & & 23 & 2.95 & 0.22 & 3.32 & 0.05 & 68 & $73=$ & \\
\hline USA - Univ. Nebraska Lincoln & 83 & 60 & & 2.94 & 0.05 & 2.09 & 0.04 & 120 & & \\
\hline Belgium. - Univ. Ghent & 84 & & 24 & 2.92 & 0.07 & 1.62 & 0.05 & 151 & & \\
\hline Singapore - Management U. & 85 & & 25 & 2.92 & 0.15 & 1.57 & 0.04 & 157 & & \\
\hline USA - Univ. Iowa & 86 & 61 & & 2.92 & -0.20 & 1.93 & 0.05 & 132 & $41=$ & 53 \\
\hline USA - Univ. Oklahoma & 87 & 62 & & 2.88 & -0.01 & 3.10 & 0.07 & 78 & & $71=$ \\
\hline USA - Univ. Colorado at Boulder & 88 & 63 & & 2.79 & -0.44 & 1.26 & 0.12 & 183 & & 66 \\
\hline USA - Temple Univ. & 89 & 64 & & 2.77 & -0.04 & 2.48 & 0.06 & 97 & $81=$ & 84 \\
\hline USA - Princeton Univ. & 90 & 65 & & 2.69 & 0.01 & 1.99 & 0.09 & 128 & & \\
\hline USA - Univ. Illinois & 91 & 66 & & 2.67 & -0.16 & 2.55 & 0.06 & 95 & & \\
\hline USA - WORLD BANK & 92 & 67 & & 2.66 & -0.66 & 1.44 & 0.21 & 167 & & \\
\hline Denmark - Univ. Copenhagen & 93 & & 26 & 2.65 & 0.13 & 2.43 & 0.03 & 99 & & \\
\hline USA - Virginia Polytech Inst & 94 & 68 & & 2.61 & -0.16 & 2.88 & 0.07 & 84 & & 95 \\
\hline USA - Int Monetary Fund & 95 & 69 & & 2.59 & -0.01 & 1.61 & 0.08 & 152 & & \\
\hline USA - Rensselaer Polytech. Inst. & 96 & 70 & & 2.57 & 0.11 & 2.21 & 0.05 & 109 & & \\
\hline USA - Babson Coll. & 97 & 71 & & 2.57 & 0.18 & 2.76 & 0.06 & 88 & $81=$ & \\
\hline USA - Tulane Univ. & 98 & 72 & & 2.56 & 0.06 & 2.85 & 0.03 & 86 & $62=$ & 56 \\
\hline USA - Univ. Houston & 99 & 73 & & 2.45 & -0.16 & 2.30 & 0.08 & 106 & & $74=$ \\
\hline USA - Univ. T'ssee Knoxville & 100 & 74 & & 2.44 & 0.03 & 2.24 & 0.06 & 108 & & \\
\hline Canada - Simon Fraser Univ. & 101 & & 27 & 2.43 & 0.02 & 1.77 & 0.05 & 139 & & 94 \\
\hline USA - Texas San Antonio & 102 & 75 & & 2.43 & 0.09 & 1.78 & 0.03 & 138 & & \\
\hline USA - Univ. Kentucky & 103 & 76 & & 2.43 & 0.08 & 3.30 & 0.09 & 71 & & $89=$ \\
\hline Singapore - Nanyang Tech & 104 & & 28 & 2.43 & 0.15 & 2.30 & 0.03 & 107 & $73=$ & $74=$ \\
\hline UK - Univ. Cambridge & 105 & & 29 & 2.39 & 0.12 & 3.30 & 0.06 & 70 & $51=$ & \\
\hline UK - Univ. Warwick & 106 & & 30 & 2.38 & 0.13 & 4.04 & 0.07 & 54 & $81=$ & \\
\hline Australia - Univ. Queensland & 107 & & 31 & 2.35 & 0.11 & 2.19 & 0.05 & 110 & & \\
\hline USA - Drexel Univ. & 108 & 77 & & 2.34 & 0.06 & 1.99 & 0.03 & 129 & & \\
\hline Canada - McGill Univ. & 109 & & 32 & 2.31 & -0.10 & 1.94 & 0.07 & 130 & $45=$ & 63 \\
\hline UK - Univ. London L.S.E. & 110 & & 33 & 2.22 & 0.01 & 2.66 & 0.05 & 92 & & \\
\hline USA - S. Methodist Univ. & 111 & 78 & & 2.22 & -0.13 & 2.48 & 0.09 & 96 & $62=$ & 62 \\
\hline USA - Univ. Cent Florida & 112 & 79 & & 2.22 & 0.23 & 3.29 & 0.05 & 72 & & \\
\hline USA - Univ. S. Florida & 113 & 80 & & 2.20 & 0.09 & 2.12 & 0.04 & 116 & & \\
\hline Netherlands - Eindhoven & 114 & & 34 & 2.19 & 0.12 & 1.72 & 0.03 & 147 & & \\
\hline USA - Univ. Mississippi & 115 & 81 & & 2.19 & 0.09 & 1.89 & 0.05 & 134 & & \\
\hline USA - Univ. Calif Davis & 116 & 82 & & 2.19 & 0.04 & 2.38 & 0.08 & 103 & 30 & 69 \\
\hline
\end{tabular}


Italy - Bocconi Univ. 117

UK - Univ. Cranfield 118

Israel - Hebrew Univ. Jerusalem 119

UK - City Univ. 120

USA - SUNY Binghamton $\quad 121$

Canada - York Univ. 122

South Korea - Yonsei Univ. 123

Netherlands - Amsterdam 124

USA - Univ. Dayton 125

USA - Univ. N Carolina $\quad 126$

Australia - Monash Univ. $\quad 127$

USA - Oklahoma State Univ. $\quad 128$

USA - Georgetown Univ. $\quad 129$

New Zealand - Univ. Auckland $\quad 130$

Australia - Univ. Sydney 131

USA - Univ. Wisconsin - M'kee 132

USA - Texas Christian Univ. 133

Germany - Univ. Mannheim 134

New Zealand - Univ. Victoria 135

UK - Univ. Lancaster 136

USA - Bentley Coll 137

USA - Univ. Illinois at Chicago 138

USA - Univ. Missouri - Columbia 139

USA - Univ. Memphis $\quad 140$

Sweden - Stockholm Sch Econ $\quad 141$

Finland - Univ. Helsinki $\quad 142$

Austria - Univ. Vienna 143

USA - Iowa State Univ.

USA - George Mason Univ.

France - HEC

Canada - Univ. Calgary

USA - Northeastern Univ.

USA - Univ. Colorado Denver

USA - Univ. Utah

USA - Texas Tech Univ.

Netherlands - Univ. Twente

USA - Rice Univ.

UK - Univ. Aston

USA - Univ. Oregon

P R China. - H. Kong Polytech

USA - North Carolina State Univ.

Switzerland - Univ. St Gallen

Canada - Univ. Waterloo

Germany - Max Planck Jena

UK. - Univ. De Montfort

USA - Univ. Delaware

UK - Univ. Strathclyde

USA - Texas Richardson

USA - Wichta State Univ.

France - Univ. Toulouse

USA - Wayne State Univ.

South Korea - Seoul National

UK - Univ. Birmingham

USA - Florida Atlantic Univ.

USA - St Louis Univ.

USA - Brigham Young Univ.

P R China - Univ. Hong Kong

USA - San Diego State Univ.

Australia - Griffith Univ.

USA - Univ. Rochester

Norway - Univ. Bergen

83

83

84

85

86

87

88

89

144

145

146

147

148

149

150

151

152

153

154

155

156

157

158

159

160

161

162

163

164

165

166

167

168

169

170

171

172

173

174

175

176

177

90

91

92

93

94

95

96

97

98

99

100

101

102

103

104

105

106

107

108

109

110

111

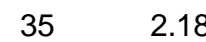

$$
36
$$

37

38

2.11

2.11
2.11

\begin{tabular}{l}
$38-2.11$ \\
\hline
\end{tabular}

2.09

$\begin{array}{ll}39 & 2.07\end{array}$

$40 \quad 2.06$

$41 \quad 2.05$

2.00

1.94

$42 \quad 1.94$

1.92

1.92

$43 \quad 1.91$

44

1.90

1.86

1.85

$45 \quad 1.83$

$46 \quad 1.83$

$47 \quad 1.82$

$\begin{array}{ll}56 & 1.59 \\ 5 & 1.54\end{array}$

$57 \quad 1.53$

$58 \quad 1.50$

$59 \quad 1.50$

1.44

$60 \quad 1.41$

1.39

1.36

$61 \quad 1.36$

1.36

$62 \quad 1.35$

$63 \quad 1.34$

0.21

0.09

0.01

0.08

0.07

0.07

0.06

0.09

0.08

0.01

0.10

$-0.10$

- 0.06

0.09

0.11

$-0.04$

0.07

0.10

0.05

0.09

0.08

0.05

$-0.06$

0.11

0.08

0.13

0.10

0.04

0.06

0.02

0.02

0.09

0.03

0.06

$-0.19$

0.07

0.15

0.12

0.04

0.22

$-0.01$

0.07

0.00

0.05

0.10

0.03

0.14

0.01

0.06

0.06

$-0.04$

0.13

0.07

$-0.01$

0.04

0.12

0.14

0.04

0.10

$-0.21$

0.06
$2.74 \quad 0.04$

$\begin{array}{ll}1.92 & 0.05\end{array}$

$2.61 \quad 0.10$

$\begin{array}{ll}1.79 & 0.03\end{array}$

$\begin{array}{ll}2.02 & 0.07\end{array}$

$2.06 \quad 0.04$

$1.00 \quad 0.03$

$2.14 \quad 0.06$

$1.27 \quad 0.03$

$\begin{array}{ll}1.58 & 0.06\end{array}$

$2.00 \quad 0.04$

$1.15 \quad 0.06$

$2.81 \quad 0.10$

$2.10 \quad 0.06$

$\begin{array}{ll}1.77 & 0.04\end{array}$

$1.57 \quad 0.04$

$1.43 \quad 0.03$

$1.77 \quad 0.05$

$1.25 \quad 0.04$

$2.16 \quad 0.05$

$1.65 \quad 0.03$

$\begin{array}{ll}2.92 & 0.05\end{array}$

$2.14 \quad 0.06$

$2.05 \quad 0.07$

$2.33 \quad 0.05$

$2.18 \quad 0.04$

$\begin{array}{ll}1.51 & 0.03\end{array}$

$2.31 \quad 0.05$

$\begin{array}{ll}1.99 & 0.05\end{array}$

$1.03 \quad 0.04$

$\begin{array}{ll}1.81 & 0.06\end{array}$

$2.44 \quad 0.07$

1.210 .06

$3.20 \quad 0.11$

$0.86 \quad 0.08$

$\begin{array}{ll}1.05 & 0.02\end{array}$

$3.32 \quad 0.06$

$\begin{array}{ll}1.69 & 0.02\end{array}$

$2.08 \quad 0.06$

$3.12 \quad 0.05$

$\begin{array}{ll}1.77 & 0.04\end{array}$

$1.06 \quad 0.03$

$0.96 \quad 0.05$

$0.54 \quad 0.02$

$\begin{array}{ll}1.43 & 0.03\end{array}$

$2.18 \quad 0.07$

$\begin{array}{ll}2.18 & 0.07 \\ 2.63 & 0.05\end{array}$

$1.20 \quad 0.06$

$0.87 \quad 0.03$

$1.51 \quad 0.04$

$1.23 \quad 0.06$

$\begin{array}{ll}1.74 & 0.03\end{array}$

$1.71 \quad 0.04$

$\begin{array}{ll}1.27 & 0.06\end{array}$

$\begin{array}{ll}1.07 & 0.03\end{array}$

$2.85 \quad 0.06$

$2.09 \quad 0.03$

$\begin{array}{ll}1.28 & 0.03\end{array}$

$\begin{array}{ll}1.39 & 0.02\end{array}$

$\begin{array}{ll}1.60 & 0.09\end{array}$

$\begin{array}{ll}1.45 & 0.04\end{array}$

$9073=$

$13386=$

94

137 


\begin{tabular}{|c|c|c|c|c|c|c|c|c|c|c|}
\hline USA - Univ. Texas Dallas & 178 & 112 & & 1.27 & -0.13 & 0.39 & 0.06 & 288 & & 35 \\
\hline Spain - Univ. Carlos III Madrid & 179 & & 67 & 1.26 & 0.08 & 1.22 & 0.03 & 189 & & \\
\hline USA - Washington State Univ. & 180 & 113 & & 1.22 & 0.00 & 2.42 & 0.09 & 100 & & 85 \\
\hline USA - New Mexico State Univ. & 181 & 114 & & 1.20 & 0.06 & 1.00 & 0.03 & 217 & & \\
\hline UK - Univ. Reading & 182 & & 68 & 1.20 & 0.06 & 1.31 & 0.04 & 177 & & \\
\hline Taiwan - Natl Chiao Tung Univ. & 183 & & 69 & 1.20 & 0.05 & 0.73 & 0.02 & 251 & & \\
\hline P R China - Univ. Beijing & 184 & & 70 & 1.19 & 0.09 & 1.02 & 0.03 & 210 & & \\
\hline UK - Univ. Bath & 185 & & 71 & 1.19 & 0.06 & 1.51 & 0.03 & 160 & $58=$ & \\
\hline USA - Univ. Hawaii & 186 & 115 & & 1.19 & -0.14 & 0.63 & 0.08 & 266 & & \\
\hline South Korea - Korea Univ. & 187 & & 72 & 1.19 & 0.07 & 1.29 & 0.04 & 178 & & \\
\hline USA - Wake Forest Univ. & 188 & 116 & & 1.18 & 0.10 & 1.93 & 0.03 & 131 & $51=$ & 99 \\
\hline Denmark - Univ. Aarhus & 189 & & 73 & 1.18 & 0.10 & 1.37 & 0.02 & 173 & & \\
\hline USA - DePaul Univ. & 189 & 117 & & 1.18 & 0.03 & 0.94 & 0.03 & 229 & & \\
\hline USA - Baylor Univ. & 191 & 118 & & 1.18 & 0.04 & 1.00 & 0.03 & 218 & & \\
\hline Switzerland - Zurich & 192 & & 74 & 1.17 & 0.07 & 0.77 & 0.02 & 246 & & \\
\hline UK - Univ. Leeds & 193 & & 75 & 1.17 & 0.03 & 1.73 & 0.06 & 146 & $73=$ & \\
\hline USA - Univ. Kansas & 194 & 119 & & 1.16 & 0.02 & 1.81 & 0.05 & 135 & & \\
\hline Canada - Wilfrid Laurier Univ. & 195 & & 76 & 1.16 & 0.05 & 1.11 & 0.02 & 197 & & \\
\hline Canada - Univ. Manitoba & 196 & & 77 & 1.16 & 0.03 & 0.92 & 0.03 & 231 & & \\
\hline USA - Univ. Akron & 197 & 120 & & 1.16 & -0.10 & 0.51 & 0.06 & 279 & & \\
\hline UK - Univ. Loughborough & 198 & & 78 & 1.15 & 0.06 & 1.01 & 0.02 & 213 & & \\
\hline USA - Univ. Calif Riverside & 199 & 121 & & 1.15 & -0.08 & 0.95 & 0.06 & 225 & & 83 \\
\hline Netherlands - Free Univ. A'rdam & 200 & & 79 & 1.14 & 0.08 & 1.75 & 0.04 & 143 & & \\
\hline Israel - Tel Aviv Univ. & 201 & & 80 & 1.13 & -0.25 & 1.23 & 0.11 & 188 & & \\
\hline UK - Univ. Leicester & 202 & & 81 & 1.12 & 0.06 & 0.99 & 0.02 & 219 & & \\
\hline Ireland - Univ. Coll Dublin & 203 & & 82 & 1.10 & 0.04 & 0.79 & 0.03 & 244 & 91 & \\
\hline USA - Florida Inst of Technology & 204 & 122 & & 1.09 & -0.16 & 0.96 & 0.05 & 222 & & \\
\hline USA - Univ. Calif Santa Barbara & 205 & 123 & & 1.09 & 0.05 & 1.07 & 0.03 & 203 & & \\
\hline UK - Univ. Sussex & 206 & & 83 & 1.09 & 0.00 & 1.48 & 0.07 & 165 & & \\
\hline Canada - Univ. Quebec & 207 & & 84 & 1.06 & 0.02 & 0.97 & 0.03 & 220 & & \\
\hline USA - Clemson Univ. & 208 & 124 & & 1.06 & -0.23 & 0.17 & 0.06 & 297 & & \\
\hline Sweden - Lund Univ. & 209 & & 85 & 1.03 & 0.10 & 1.33 & 0.03 & 176 & & \\
\hline USA - IBM & 210 & 125 & & 1.02 & -0.05 & 0.75 & 0.04 & 248 & & \\
\hline Australia - Natl Univ. & 211 & & 86 & 1.02 & -0.04 & 0.91 & 0.05 & 233 & & \\
\hline Netherlands - Univ. Tech Delft & 212 & & 87 & 1.01 & 0.04 & 0.97 & 0.02 & 221 & & \\
\hline USA - Old Dominion Univ. & 213 & 126 & & 1.00 & 0.01 & 0.88 & 0.02 & 238 & & \\
\hline Italy - Univ. Bologna & 214 & & 88 & 1.00 & 0.06 & 1.01 & 0.02 & 211 & & \\
\hline
\end{tabular}

\section{All data are citation weighted counts of Journal Publication Share Figures are parts per '000}

The Forecast for 2006 is based on trend data from 1992 to 2005

The Forecast rank inevitably misses some data, as it takes into account institutions not listed here, Several schools in the FT Global MBA ranking are not in our list but we preserve their ranking numbers In the Dallas list we have tried to allocate all schools but there are a few omissions due to ambiguity in the correspondence between schools and universities

(c) In table and data V. Mangematin \& C. Baden - Fuller, 2007 reproduced under licence 


\section{Appendix Table: Journals Ranked by Impact Factor in 2005}

\begin{tabular}{|c|c|c|c|}
\hline JOURNALS & IF2005 & TC2005 & JCR Categories \\
\hline Mis Quart & 4.978 & 2395 & Information science and library science, Management \\
\hline Acad Manage Rev & 4.254 & 6387 & Business, Management \\
\hline J Marketing & 4.132 & 5307 & Business \\
\hline Market Sci & 3.788 & 1724 & Business \\
\hline Admin Sci Quart & 2.719 & 5906 & Business, Management \\
\hline J Market Res - Chicago & 2.611 & 4495 & Business \\
\hline J Finan & 2.549 & 8235 & Business - finance \\
\hline J Finan Econ & 2.385 & 5404 & Business - finance, Economics \\
\hline Hum Resource Manage & 2.378 & 1167 & Industrial relations \& labor, Management \\
\hline Acad Manage J & 2.2 & 6944 & Business, Management \\
\hline J Consum Res & 2.161 & 4356 & Business \\
\hline J Risk Uncertainty & 2.1 & 880 & Business - finance, Economics \\
\hline Organ Sci & 1.989 & 3142 & Management \\
\hline Strategic Manage & 1.897 & 6137 & Business, Management \\
\hline Rev Financ Stud & 1.893 & 1984 & Business - finance \\
\hline J Account Econ & 1.877 & 1413 & Business - finance, Economics \\
\hline J Bus Venturing & 1.846 & 1279 & Business \\
\hline Res Policy & 1.835 & 2470 & Management, Planning and development \\
\hline Leadership Quarterly & 1.75 & 794 & Psychology - applied, Management \\
\hline Account Rev & 1.69 & 1256 & Business - finance \\
\hline Manage Sci & 1.669 & 8367 & Management \\
\hline J Account Res & 1.635 & 1343 & Business - finance \\
\hline J Inform Technol & 1.543 & 347 & Information science and library science, Management \\
\hline J Manage & 1.535 & 2562 & Business, Management \\
\hline J Environ Econ Manage & 1.529 & 1714 & Business, Economics, Environemental Studies \\
\hline Inform Management & 1.524 & 1230 & Information science and library science, Management \\
\hline J Acad Mark Sci & 1.485 & 1336 & Business \\
\hline J Public Adm Res Theory & 1.451 & 416 & Public Administration \\
\hline Financ Stoch & 1.429 & 397 & Business - finance \\
\hline J Manage Inform Syst & 1.406 & 1167 & Information science and library science, Management \\
\hline Harvard Business & 1.404 & 4475 & Business, Management \\
\hline Governance & 1.349 & 294 & Public Administration \\
\hline Math Financ & 1.345 & 672 & Business - finance \\
\hline J Manage Stud - Oxford & 1.326 & 1622 & Business, Management \\
\hline Acad Manage Exec & 1.319 & 930 & Business, Management \\
\hline Organization & 1.28 & 507 & Management \\
\hline Organ Stud & 1.278 & 1187 & Management \\
\hline Organ Behav Hum Decision Proc & 1.275 & 3482 & Psychology applied, Management, Psychology social \\
\hline World Bank Econ Rev & 1.27 & 577 & Business - finance, Economics, Planning \& dev't \\
\hline J Int Bus Stud & 1.25 & 1788 & Business, Management \\
\hline Int J Res Mark & 1.222 & 592 & Business \\
\hline Entrep Reg Dev & 1.174 & 318 & Economics, Management \\
\hline J Public Policy Marketing & 1.158 & 395 & Business, Public Administration \\
\hline Int J Electron Commer & 1.143 & 292 & Business, Information science and library science \\
\hline New Technol Work Employ & 1.129 & 123 & Ergonomics Management \\
\hline J Financ Intermed & 1.118 & 278 & Business - finance \\
\hline Int J Manag Rev & 1.111 & 74 & Business, Management \\
\hline Organ Res Methods & 1.103 & 277 & Business, Management \\
\hline Public Admin Rev & 1.099 & 1197 & Public Administration \\
\hline J Organ Behav Manage & 1.074 & 220 & Psychology - applied, Management \\
\hline Decision Sci & 1.055 & 1325 & Management \\
\hline Long Range Plann & 1.054 & 595 & Business, Management, Planning and development \\
\hline Calif Manage Rev & 1.018 & 1274 & Business, Management \\
\hline J Finan Quant Anal & 1.00 & 1027 & Business - finance, Economics \\
\hline J Money Credit Banking & 0.98 & 1128 & Business - finance \\
\hline Finan Manage & 0.976 & 471 & Business - finance \\
\hline J Financ Mark & 0.974 & 176 & Business - finance \\
\hline
\end{tabular}




\begin{tabular}{|c|c|c|c|}
\hline Manage Learning & 0.952 & 246 & Management \\
\hline Public Admin & 0.924 & 580 & Public Administration \\
\hline J Prod Innovat Manage & 0.917 & 867 & Business, Management \\
\hline J World Bus & 0.895 & 279 & Business \\
\hline J Retail & 0.894 & 1037 & Business \\
\hline J Corp Financ & 0.883 & 221 & Business - finance \\
\hline Account Organ Soc & 0.871 & 701 & Business - finance \\
\hline leee Trans Eng Manage & 0.864 & 623 & Business, Management \\
\hline Psychol Market & 0.857 & 553 & Business, Psychology - applied \\
\hline J Policy Anal Manag & 0.855 & 596 & Public Administration \\
\hline Brit $\mathrm{J}$ Manage & 0.855 & 420 & Business, Management \\
\hline Nat Tax J & 0.84 & 777 & Business - finance, Economics \\
\hline J Econ Manage Strategy & 0.84 & 360 & Economics, Management \\
\hline Hum Relat & 0.817 & 2140 & Management, Social sciences - interdiscipinary \\
\hline Technol Forecast Soc Change & 0.811 & 532 & Business, Planning and development \\
\hline J Bus & 0.792 & 1575 & Business \\
\hline Bus Ethics Q & 0.778 & 313 & Business, Management \\
\hline J Manage Inquiry & 0.778 & 218 & Management \\
\hline Ind Market Manag & 0.763 & 697 & Business, Management \\
\hline Contemp Account Res & 0.759 & 401 & Business \\
\hline Bus Hist & 0.755 & 133 & Business, History of social sciences \\
\hline Int J Forecasting & 0.753 & 642 & Management, Planning and development \\
\hline World Econ & 0.746 & 400 & Business - finance, Economics, International relations \\
\hline J Adver Res & 0.743 & 847 & Business, communication \\
\hline Mit Sloan Manage Rev & 0.719 & 173 & Business, Management \\
\hline Organ Dyn & 0.712 & 566 & Business, Psychology - applied, Management \\
\hline Admin Soc & 0.7 & 238 & Public Administration \\
\hline Group Decis Negotiation & 0.696 & 189 & Management, Social sciences - interdiscipinary \\
\hline J Bus Res & 0.694 & 1267 & Business \\
\hline J Small Bus Management & 0.661 & 454 & Management \\
\hline Omega - Int J Manage Sci & 0.648 & 704 & Management \\
\hline $\mathrm{J}$ Bus Ethics & 0.636 & 1735 & Business, Ethics \\
\hline Int J Service Ind Management & 0.635 & 320 & Management \\
\hline Group Organ Manage & 0.622 & 467 & Psychology - applied, Management \\
\hline Int J Selection Assessment & 0.618 & 252 & Psychology - applied, Management \\
\hline Amer Rev Public Adm & 0.615 & 120 & Public Administration \\
\hline J Oper Res Soc & 0.603 & 1941 & Management \\
\hline Int J Oper Prod Manage & 0.597 & 1038 & Management \\
\hline J Bus Psychol & 0.574 & 252 & Business, Psychology - applied \\
\hline Auditing - J Pract Theor & 0.562 & 176 & Business - finance \\
\hline Tourism Manage & 0.56 & 520 & Environmental Studies, Management \\
\hline J Forecasting & 0.552 & 468 & Management, Planning and development \\
\hline $\mathrm{J}$ Ind Econ & 0.551 & 957 & Business - finance, Economics \\
\hline Financ Anal J & 0.542 & 547 & Business - finance \\
\hline J Bank Finan & 0.531 & 1142 & Business - finance, Economics \\
\hline Interfaces & 0.524 & 686 & Management \\
\hline R D Manage & 0.506 & 417 & Business, Management \\
\hline $\mathrm{J}$ Int Money Finan & 0.505 & 699 & Business - finance \\
\hline J Bus Tech Commun & 0.5 & 70 & Business, communication \\
\hline J Prod Anal & 0.492 & 420 & Business, Economics, Soc sciences - math methods \\
\hline $\mathrm{J}$ Advertising & 0.491 & 642 & Business, communication \\
\hline Amer Bus Law J & 0.481 & 110 & Business, Law \\
\hline J Real Estate Financ Econ & 0.473 & 345 & Business - finance, Economics, Urban studies \\
\hline J Consum Aff & 0.465 & 251 & Business \\
\hline J Portfolio Manage & 0.464 & 331 & Business - finance \\
\hline Environ Plan C - Gov Policy & 0.462 & 280 & Environmental Studies, Public Administration \\
\hline Mark Lett & 0.448 & 301 & Business \\
\hline Adv Strat M & 0.444 & 120 & Business, Management \\
\hline $\mathrm{J}$ Int Marketing & 0.429 & 209 & Business \\
\hline Rev Industrial Organ & 0.388 & 255 & Economics, Management \\
\hline Res Technol Manage & 0.385 & 274 & Business, Management \\
\hline
\end{tabular}




\begin{tabular}{|c|c|c|c|}
\hline Syst Dynam Rev & 0.379 & 185 & Management, Social sciences - math methods \\
\hline Syst Res Behav Sci & 0.375 & 115 & Management, Social sciences - interdiscipinary \\
\hline Int Mark Rev & 0.364 & 282 & Business \\
\hline Aust J Publ Adm & 0.338 & 187 & Public Administration \\
\hline J Risk Ins & 0.328 & 238 & Business - finance, Economics \\
\hline Syst Pract Action Res & 0.327 & 57 & Management \\
\hline J Futures Markets & 0.317 & 351 & Business - finance \\
\hline J Organ Change Manage & 0.307 & 269 & Management \\
\hline Serv Ind J & 0.303 & 213 & Management \\
\hline Bus Hist Rev & 0.276 & 175 & Business, History of social sciences \\
\hline Int J Market Res & 0.269 & 57 & Business \\
\hline Public Interest & 0.268 & 220 & Public Administration, Social issues \\
\hline Emerg Mark Financ Trade & 0.259 & 16 & Business - finance \\
\hline Total Qual Manag Bus Excell & 0.253 & 434 & Management \\
\hline Negotiation $\mathrm{J}$ & 0.245 & 132 & Management, Social sciences - interdiscipinary \\
\hline Int J Technol Manage & 0.24 & 337 & Management \\
\hline Int J Financ Econ & 0.234 & 112 & Business - finance \\
\hline Int Rev Adm Sci & 0.211 & 122 & Public Administration \\
\hline Geneva Pap Risk Insur - Iss Pr & 0.192 & 36 & Business - finance, Economics \\
\hline Can J Adm Sci & 0.191 & 96 & Business, Management \\
\hline Financ A Uver & 0.173 & 36 & Business - finance \\
\hline Int J Manpower & 0.171 & 131 & Management \\
\hline Admin Soc Work & 0.146 & 137 & Public Administration, Social work \\
\hline Public Pers Manage & 0.119 & 167 & Industrial relations \& labor, Public Administration \\
\hline Can Publ Admin & 0.067 & 69 & Public Administration \\
\hline Advan Consum Res & 0.031 & 727 & Business \\
\hline \multicolumn{4}{|c|}{ Journals Once Included But Now Excluded } \\
\hline \multicolumn{3}{|c|}{ Human Resource Manag'nt Rev } & Psychology - applied, Management \\
\hline \multicolumn{3}{|c|}{ J Collect Neg Pub Sec } & Industrial relations \& labor, Public Admin., Manag'nt \\
\hline \multicolumn{3}{|c|}{ J Finan Serv Res } & Business - finance \\
\hline \multicolumn{3}{|c|}{ J Market Res Soc } & Business \\
\hline \multicolumn{2}{|c|}{ Russ East Eur Financ Trade } & & Business, International relations \\
\hline
\end{tabular}

\section{Notes:}

IF 2005: Impact Factor for 2005

TC2005: Total citations for the journal in 2005

Source: Thompson ISI 


\section{References}

${ }^{1}$ S. R. Barley, G. W. Meyer and D. C. Gash, Cultures of culture: Academics, practitioners and the pragmatics of normative control, Administrative Science Quarterly 33: 24-60 (1988).

${ }^{2}$ S. H. Park and M. E. Gordon, Publication Records and Tenure Decisions in the Field of Strategic Management, Strategic Management Journal 17(2): 109-128 (1996); A. Siow, Tenure and Other Unusual Personnel practices in Academia, Journal of Law, Economics and Organization 14(1): 152-173 (1998); P. Verhaegen, Academic talents: Quo Vadis? Recruitment and retention of faculty in European Business Schools, Journal of Management Development 24(9): 807-818 ) (2005).

3 AACSB, The Impact of Research Task Force Report (2007); M. Harmon, Business Research and Chinese Patriotic poetry: How competition for status distorts the priority between Research and Teaching in US Business Schools, Academy of Management Learning and Education 5(2): 234-243 (2006).

${ }^{4}$ C. Baden-Fuller and S. Hwee Ang Building reputations: The role of Alliance in the European Business School Scene, Long Range Planning 34:741 (2001).

${ }^{5}$ See for example the work of Bourdieu on social capital, which has deeply influenced research on networks, or of Crozier, who is highly cited by worldwide scholars for his contribution on bureaucracy. In the same vein, Lorenzoni's work on Italian Industrial Districts deeply influenced both Piore and Sable's work and that of Michael Porter on Global Competition, and likewise Pettigrew's work has had a profound influence on US research into change management and change practices.

${ }^{6}$ M. L. Djelic and R. P. Amdam, Americanization in Comparative Perspective: The Managerial Revolution in France and Norway 1940-1990, Business History 49(4): 483505 (2007); M. L. Djelic, Has Europe been Americanized? The competition perspective, PKU Business Review 32(3): 122-129 (2007).

${ }^{7}$ D. Antunes and $\mathrm{H}$. Thomas, The competitive (dis)advantages of European Business Schools, Long Range Planning 40(3): 382-404 (2007); K. Leung, The glory and tyranny of citation impacts: an East Asian perspective, Academy of Management Journal 50(3): 510-513 (2007).

${ }^{8}$ B. Latour, Science in Action, Harvard University Press: Cambridge (MA) (1987); M. Tushman, C. O'Reilly, A. Fenollosa, A. M. Klieinbaum and D. McGrath, Relevance and Rigor: Executive education as a lever in shaping practice and research, Academy of Management Learning and Education 6(3): 345-362 (2007); A. Van de Ven and P. Johnson, Knowledge for theory and practice. Academy of Management Review 31(4): 516-531 (2006).

${ }^{9}$ Cited in R. Merton, On the shoulders of giants: a Shandean postscript, Free Press: New York (1965).

10 An analysis of the research outputs of all UK universities has revealed that $80 \%$ was in scientific journals, with book chapters accounting for a further $10 \%$. For a further perspective on this topic see P. Laredo, M. Callon, P. Mustar, A. Birac and B. Fourest, Defining the Strategic Profile of Research Labs: the Research Compass Card Method, in A. Van Raan (Ed.), Science and Technology in a Policy Context, DSWO Press: Leiden (1992). Our method also recognises that research which takes place in specialised scientific communities can be widely disseminated across communities. For example, social science scholars that innovate new econometric or bibliometric tools publish in a narrow range of journals, yet this knowledge is used across all fields of social science; likewise important developments in management thinking which may first appear in a specialised narrowly focused (but high quality) journal will have a large impact on the wider community.

${ }^{11}$ S. Baldi, Prestige determinants of first academic job for new sociology PhDs 1985-1992, Sociological Quarterly, Vol. 36: 777-798 (1995); D. R. Ilgen, Citations to management 
articles: cautions for science about advice for the scientist, Academy of Management Journal 50(3): 507-509 (2007); T. A. Judge, D. M. Cable, A. E. Colbert and S. Rynes, What causes a management article to be cited: article, author or journal?, Academy of Management Journal 50(3): 491-506 (2007); R. Monasterky, The number that's devouring science, Chronicle of Higher Education October 2005; S. B. Stremersch, I. Verniers and P. C. Verhoef , The quest for citations: drivers of article impact, Journal of Marketing 71(July): 171-193 (2007).

12 L. H. Carmichael, Incentives in Academia: Why is There Tenure?, Journal of Political Economy 96(3): 453-472 (1988); A. Diamond, What is a citation worth?, The Journal of Human Resources 21(2): 200-215 (1986); Park and Gordon (1996), op cit ref 2

13 T. S. Kuhn, The Structure of Scientific Revolutions, University of Chicago Press: Chicago (1962).

${ }^{14}$ W. H. Starbuck, How much better are the most prestigious journals? The statistics of academic publication, Organization Science 16(2): 180-200 (2005);

${ }^{15}$ K. D. Elsbach and R. M. Kramer Members' Responses to Organizational Identity Threats, Administrative Science Quarterly 41:442-476 (1996).

${ }^{16}$ R. Durand and J. McGuire Legitimating Agencies in the Face of Selection, Organization Studies forthcoming (2007).

${ }^{17}$ It has been claimed that citations are not unbiased, since, given the choice, researchers will typically cite journals (and authors) that are more prestigious over those that are less well known in order to confer legitimacy on the argument they are advancing. However journal-reviewers act to rectify such biases and ensure that authors recognise properly where ideas come from. We also note that journals that pressure authors to cite only material from that journal have sometimes found their journals declining in importance.

18 See Ilgen 2007 and Judge et al. 2007, both op cit at Ref 11.

19 J. Cole and S. Cole, Measuring the quality of sociological research: Problems in the use of the Science Citation Index, The American Sociologist, Vol. 6: 23-29 (1973); D. Crane, The gatekeepers of science: some factors affecting the selection of articles for scientific journals, American Sociologist, Vol. 4: 195-201 (1967).

${ }^{20}$ P. M. Podsakoff, S. B. MacKenzie, D. G. Bachrach and N. P. Podsakoff, The influence of management journals in the 1980s and 1990s, Strategic Management Journal 26(5): 473488 (2005).

${ }^{21}$ Simply put, we undertake simple linear regression of share against time for the whole period and report the slope of the estimated equation along with the standard error of the coefficient, see for instance W. H. Greene, Econometric Analysis, New York: PrenticeHall (2005).

${ }^{22}$ Among those in this group we include: Imperial College, University of Sheffield, University of Edinburgh in the UK and University of Technology, Sydney, Australia.

${ }^{23}$ R. A. Gordon and J. E. Howell, Higher education for business, Columbia University Press: New York (1959).

${ }^{24}$ G. Dosi, Technological Paradigms and Technological Trajectories: A Suggested Interpretation of the Determinants and Directions of Technical Change, Research Policy 11: 147-162 (1982); M. Tushman and P. Anderson, Technological Discontinuities and Organizational Environments, Administrative Science Quarterly 31: 439-465 (1986).

${ }^{25}$ P. Anderson and M. L. Tushman, Technological Discontinuities and Dominant Designs: A Cyclical Model of Technological Change, Administrative Science Quarterly 35(4): 604633 (1990).

${ }^{26}$ R. Durand and J. McGuire, Legitimating agencies in the face of selection: The case of AACSB, Organization Studies 26(2): 165-196 (2005).

27 The Academy of Management Executive Journal ceased publication in 2006-7. A new journal The Academy of Management Perspectives has a different, less management oriented, mission. 